\title{
Apoptosis and Involution of Bursa of Fabricius in Chickens
}

\author{
Osamu MORIYA \\ Department of Microbiology, Saitama Medical School, \\ Moroyama, Iruma, Saitama, 350-04
}

\begin{abstract}
Apoptosis was studied in chickens with reference to bursal involution. Morphological and biochemical apoptosis occurred first on day 18 of incubation in bursa of normal embryos. Such phenomena were never detected before 18 th day of embryonic life. Therefore, apoptotic induction was stage specific in chicken bursa. Embryos treated with testosterone propionate (TP) showed DNA fragmentation on day 18, 8 days after the TP injection; these apoptotic responses were negligible on other experimental days. Furthermore, apoptotic cells were occasionally seen among the bursal lymphocytes or epithelial cells in the TP-treated embryos. Embryos injected with half dose of TP showed lower levels of DNA fragmentation than the normals, and the cells undergoing apoptosis were low in number. After hatching, apoptosis was detected morphologically and biochemically in normal bursa, especially after the stage of sexual maturation. These findings demonstrate an apparent correlation between apoptosis and normal involution of bursa after maximal stage of tissue maturation and are suggesting for an apoptosis-independent process of bursal involution introduced by TP treatment.
\end{abstract}

(Jpn. Poult. Sci., 35 : 37-46, 1998)

Key words : bursa of Fabricius, chemical bursectomy, apoptosis, chicken

\section{Introduction}

Testosterone treatment of chick embryos inhibited bursal proliferation and showed bursal involution (bursectomy; $\mathrm{Bx}$ ) and specific antibody productions were not detectable (CAREY and WARNER, 1964 ; SZENBERG and WARNER, 1962). It is well known that testosterone affects the development of the bursal epithelium, thereby preventing B cell development, leading to a small or absent bursa. Therefore, there is a possibility of apoptosis induction in bursal epithelium. In addition to the embryonic Bx, GLICK (1956) showed the natural involution of bursa after the maximal stage of bursal proliferation. This finding implies the controlled removal of bursal lymphocytes. Until now, apoptosis has been regarded as an important mechanism in selection of lymphocyte subset and controlling the size of lymphoid organs (Compton et al., 1990 ; MeyaArd et al., 1992). In chickens, B cell apoptosis has been described in proliferating bursa after hatching by many investigators (CоMPTon et al., 1990 ; МотукA and Reynolds, 1991 ; PARAmithiotics et al., 1995). However, the role of apoptosis at the stage of bursal involution is not well understood. Furthermore, there is no finding on the difference between the natural involution of bursa after the maximal stage of maturation and the embryonic $\mathrm{Bx}$ introduced by testosterone. Therefore, author studied the phenomena of two bursal involutions.

Received March 31, 1997 Accepted August 5, 1997 


\section{Materials and Methods}

White Leghorn eggs were obtained from the Saitama Prefectural Poultry Experiment Station (Saitama), and were incubated at $39^{\circ} \mathrm{C}$. Normal chicks were used from the neonatal stage to 25 weeks after hatching. Testosterone propionate (TP; $0.1 \mathrm{~m} l$ of $40 \mathrm{mg} / \mathrm{ml}$ in propylene glycol) was injected into the chorioallantoic cavity on embryonic day 10 and the bursae were found to be involuted just before hatching (CAREY and W ARNER, 1964). Chicks of partial Bx were obtained by injecting the TP of half dose (2 $\mathrm{mg} / \mathrm{egg}$ ) for $\mathrm{Bx}$ induction into the embryonic chickens. To avoid the preparation of intestinum crassum instead of bursal trace after the TP treatment, bursae were separated and checked histologically for the degenerating process. Three (adult stage) to eight (embryonic and young stages) chickens were used in each experimental day.

Bursae at various stages of development (day 12 to day 20 of embryo, 3 days to 25 weeks after hatching) were placed in $2 \%$ paraformaldehyde in $0.1 \mathrm{M}$ phosphate buffer $(\mathrm{pH} 7.2)$ for fixation and embedded in paraffin. After stainings the tissue sections (10 $\mu \mathrm{m}$ thickness) with toluidine blue in sodium borate $(0.4 \%)$ or hematoxylin and eosin, these specimens were observed by light microscope. Tissue sections to be examined with an electron microscope were prepared from chick embryos at different stages of life as described above in the paraffin sections. Ultrathin sections fixed in $2 \%$ glutaraldehyde in $0.1 \mathrm{M}$ cacodylate buffer, $\mathrm{pH} 7.2$ and embedded in Epon were prepared and stained with uranyl acetate followed by lead citrate, and observed under a JEM 100 C electron microscope (MoRIYA and ICHIKAWA, 1979). Tissue sections stained with toluidine blue were simultaneously prepared.

DNA was extracted from individual bursa (day 12 of incubation to 25 weeks after hatching) using the phenol-chloroform method (NAGAHARA, 1991). DNA contents were semi-quantitated by their relative fluorescent intensity after reaction with ethidium bromide by using UV light (Transilluminator, Funakoshi, Tokyo). Equal amounts of DNA were electrophoresed in $1.8 \%$ agarose gel in $0.08 \mathrm{M}$ borate buffer, pH 8.3 with Mupid-2 system (CosmoBio, Tokyo). After electrophoresis, gels were stained with ethidium bromide $(0.5 \mu \mathrm{g} / \mathrm{ml})$ and their patterns of DNA fragmentation were then observed under UV light. Molecular weight markers of DNA fragments were $\phi$ X174 RF1 digested by Hinf I (Wako Pure Chemicals, Osaka). Apoptosis was determined by detection of DNA fragmentation (HASBOLD and KLAUS, 1990). Gels were photographed with a Polaroid camera (ACMELM 085) equipped with an instant camera Film 337 (Polaroid, Mass.).

\section{Results}

\section{Apoptosis estimation in bursa by DNA fragmentation}

Both normal and TP ( 2 or $4 \mathrm{mg}$ )-treated chickens showed the same pattern of DNA migration as higher-molecular-weight by electrophoresis from embryonic day 12, 14, and 16 and none of them showed DNA fragmentation in bursa. This result indicated the presence of intact DNA and did not show the apoptosis in these tissues. Therefore, 
no differences of DNA pattern could be seen between the normal and the Bx embryos on these days. Ladder DNA (oligomer ; 713, 500 and $249 \mathrm{bp}$ ) was first detected in the bursa of normal embryos on day 18 and were then observed constantly until hatching (Fig. 1-A). Although DNA fragmentation was visible faintly on day 18 in the $\mathrm{Bx}$ embryos, the level of DNA degradation was lower in the Bx embryos than the normals (Fig. 1-A). Such DNA fragmentation could not seen in the Bx embryos on day 19 , these bursae disappeared on about the 20 th day of embryonic development (Fig. 1-B). DNA fragmentation was faintly detected on day 19 in the embryos injected with half doses of TP (Fig. 1-B). Although there was no quantitative estimation in this study, this result indicates a lower level of apoptosis induction in the embryos by injecting half dose of TP than the normals.

Fig. 2 represents the apparent oligo-nucleosomal DNA fragmentation, thus indicating the ongoing apoptosis at 4, 8, 16, and 25 weeks after hatching in normal chickens.

Morphological demonstration of apoptotsis

Although follicle proliferations started at an early stage of bursal development, no apoptotic cells were seen in bursa at the early stage of embryonic development (Fig. 3-A). Although suppressive effects of TP on bursal proliferation were observed, especially on follicle formation beneath the epithelium, apoptotic cell was occasional in epithelium areas (Fig. 3-B). Cells representing apoptosis, such as condensed chromatins, were seen partly on day 19 of incubation in normal chickens (Fig. 3-C). After
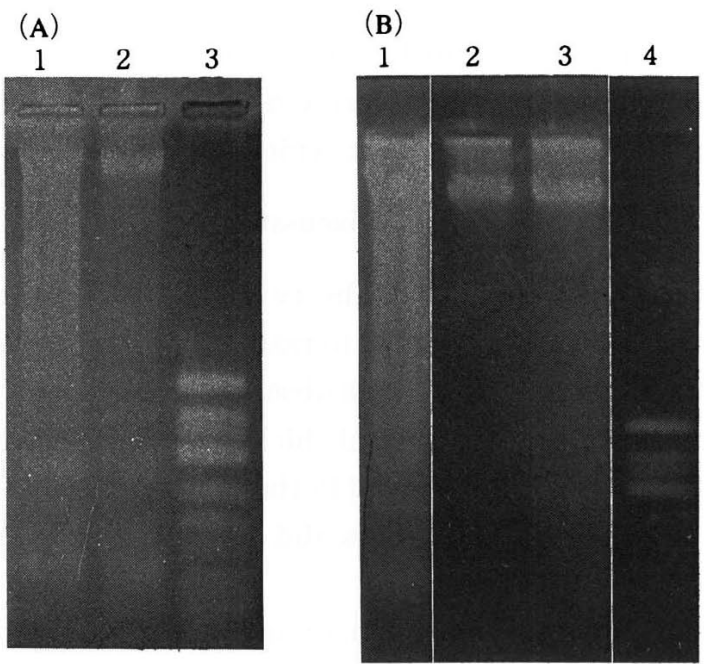

Fig. 1. Agarose gel electrophoresis of bursal DNA extracted either from normal or TP treated chick embryos. (A) Electrophoresis pattern of bursal DNA just before hatching. These data are representative of three replicated experiments. (1) Normal embryo, 18 day old;(2) TP treated embryo, 18-day-old ; (3) Molecular weight standards ; DNA fragments were $\phi \mathrm{X} 174$ RF1 digested by Hinf I (726-24 bps). (B) Effect of different dose of TP on the DNA degradation on day 19 of incubation. (1) Normal, (2) TP (4 mg)-treated, (3) TP (2 mg)-treated. (4) Molecular weight standards ; DNA fragments were $\phi \mathrm{X} 174 \mathrm{RF} 1$ digested by Hinf I (726-24 bps). 


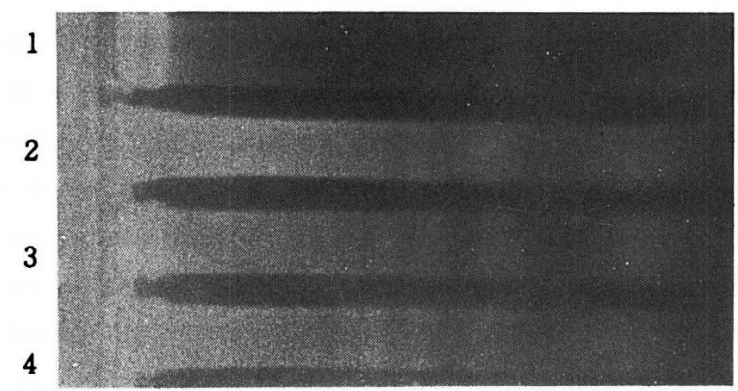

Fig. 2. Agarose gel electrophoresis of DNA extracted from normal bursa. (1) 2-week-old ; (2) 8-week-old ; (3) 16-week-old ; (4) 25-week-old Molecular weight standards were run cocurrently.

hatching, apoptotic cells were widely scattered in the medullary area of the lymphoid follicles (Fig. 3-D).

To examine the apoptosis morphologically, normal or TP-treated bursae were observed by electron microscope at various stages of bursal development. Lymphoid follicles were never visible near the surface epithelium in the Bx embryos on day 16 (Fig. 4-A). The epithelial cells were different from apoptotic cells by their clear nuclei with several nucleoli. On the contrary, some lymphocy tes were detected as apoptotic cells in normal bursa on day 18 (Fig. 4-B, 4-C). Although organelles of the apoptotic cell were not visible, condensed nuclei were demonstrated. These findings were characteristic at the later stage of cell death by apoptosis and such ultrastructural figues were frequently detected in bursa after the maximal stage of bursal proliferation. Therefore, apoptosis may be associated with natural involution of bursa (Fig. 4D). These morphological findings were widely detected in all investigated chickens.

\section{Discussion}

Morphological and biochemical observations of bursal apoptosis suggest the different mechanism(s) in the process of bursal involution between hormonal Bx before hatching and natural involution of bursa observed after hatching. Apoptotic lymphocytes were constantly detected in normal chickens a few days before hatching, whereas such apoptotic cells were never detected in the Bx embryos on the corresponding days. These findings suggest that apoptosis did not play an important role in bursal involution introduced by TP.

If the bursal rudiment was seen at hatching in TP-treated birds, lymphoid follicles without epithelial reticulum has been seen (Soos el al., 1990). Therefore, TP damages the bursal epithelium and no follicle associated epithelium has been observed. Since precise mechanism is not known concerning TP's role in the Bx, the question raises as to whether the cells of epithelium die in situ or leave undamaged in bursa. Apoptotic observation in the epithelial cells may be important for further understanding the process of hormonal $\mathrm{Bx}$. Observations of bursal apoptosis suggest the different mechanism(s) in the process of bursal involution. In normals and the embryos treated with half dose of TP, considerable numbers of lymphocyte and epithelial cell were 


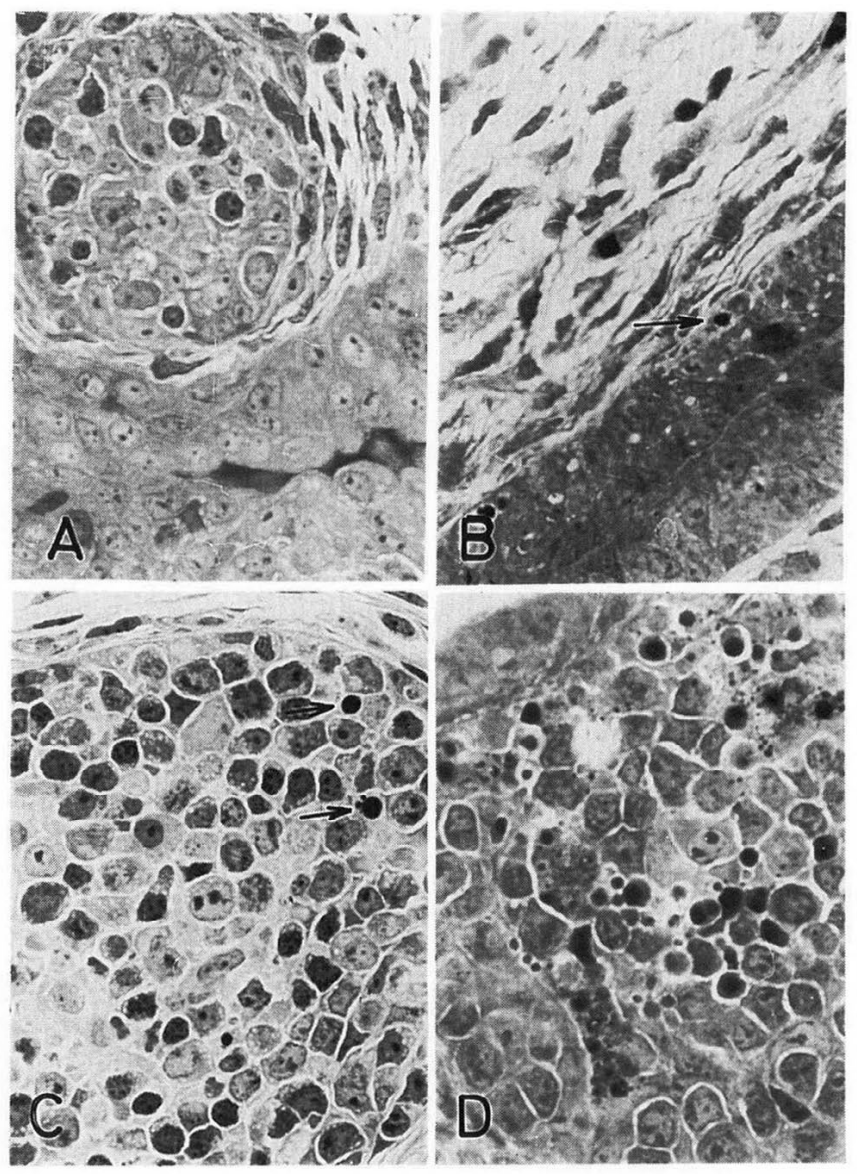

Fig. 3 Light microscopic morphology of bursa from the embryonic stage to adult stage. Sections were stained with toluidine blue. (A) Small developing follicle is seen beneath the bursal epithelium. Normal, 14-day-old embryo. $\times 775$. (B) Lymphoid follicle is never visible near the surface epithelium. Therefore, lymphocytes are rarely observed. Occasionally, there is a degenerating cell (arrow) in the epithelium. TP $(4 \mathrm{mg} / \mathrm{embryo})$-treated, 13-day-old embryo. $\times 865$. (C) Apoptotic cells (arrows) are first detected in follicular medulla. Nucleus of apoptopic cells are stained strongly with toluidine blue. Normal, 18-day-old embryo. $\times 865$. (D) Apoptotic cells are scattered widely in the medulla. Normal, 25-week-old chicken. $\times 865$.

detected in bursa. However, Bx embryos have only remnants of bursa containing epithelial cells and lymphocytes were negligible. Such tissue preparations would be unable to represent the pattern of DNA electrophoresis of bursal lymphocytes but can show the DNA pattern due to the apoptosis of epithelial cells in the Bx embryos. Although we expected DNA fragmentation in epithelial cells at the later stage of the Bx process, DNA degradation could not be detected in these Bx embryos. ScHAwrTz et $a l$. (1993) have previously reported about the diversity of apoptosis. There are possible presence of undetectable cell death mechanism in the process of Bx by TP. In this respect, missing the detection of apoptosis in TP-treated bursa may arise. Therefore, 

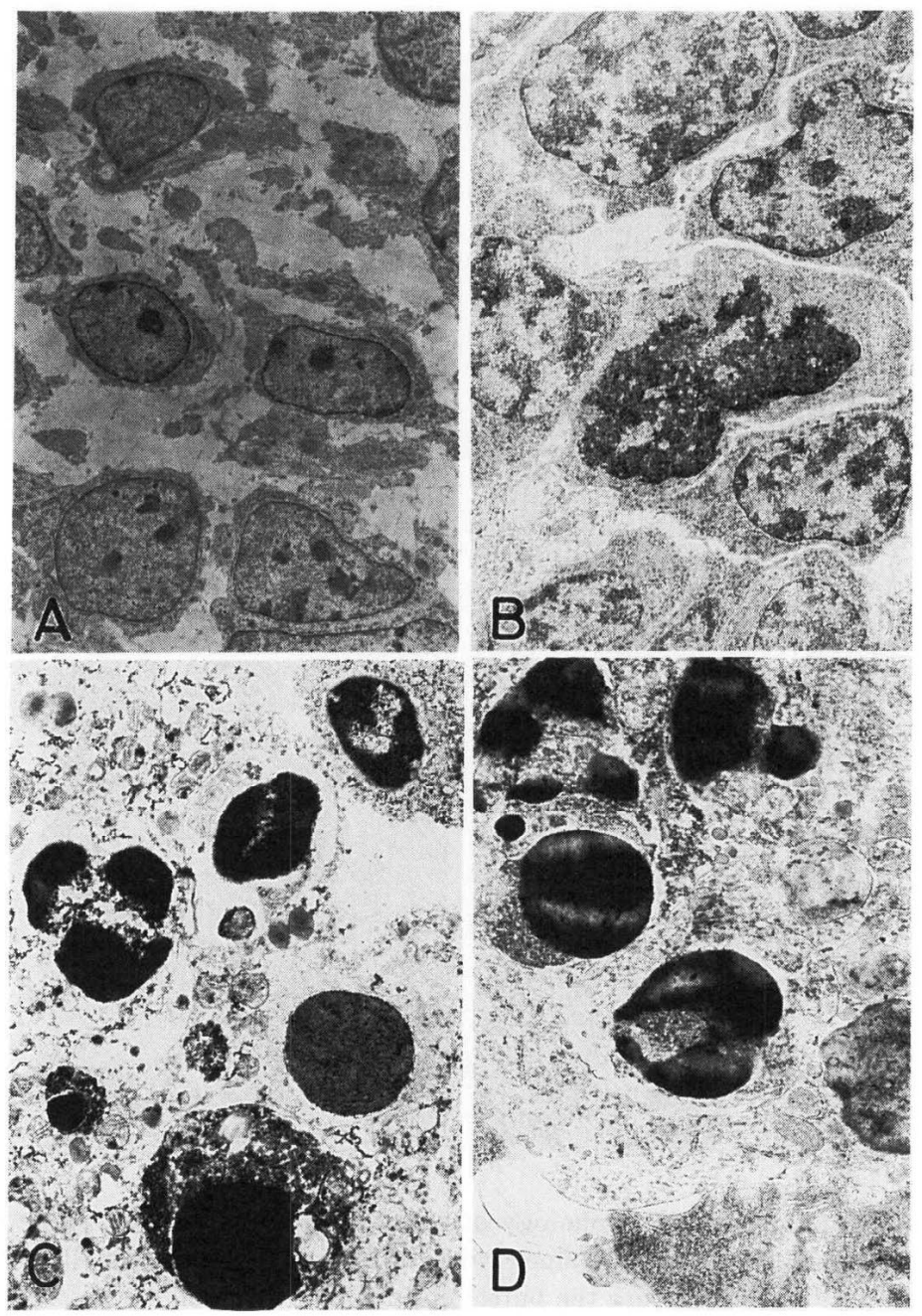

Fig. 4. Ultrastructural morphology of bursal cells. (A) Embryonic bursa after the TP injection. Epithelial cells show normal nucleus with several nucleoli. In the cytoplasm, rough endoplasmic reticulums are observed and the vesicule-like structures are seen in Golgi area. Lymphocytes are not seen. 16-day-old embryo. $\times 8,250$. (B) These bursal lymphocytes are showing uniform, normal chromatin morphology. However, it is not clear why they show the central cell with condensed chromatin. It looks like the beginning of an apoptotic process, and this seems in line with the morphology of clear cut apoptotic cells in the same tissue section. 18-day-old embryo. $\times 8,250$. (C) Bursal cells are showing typical apoptotic morphology. Apoptotic degenerating cells are frequently detected. This is photographed from the different area of the same section used in (B). 18-day-old embryo. $\times 8,250$. (D) Similar dramatic morphology of apoptosis just in time of natural bursal involution. Although, some cytoplasmic subcellular organellas are seen, nuclear morphology is absent. 25 week-old chicken. $\times 8,250$. 
remaining problem to study is the undetectable apoptosis in the epithelial cells or immature lymphocytes. More studies are necessary to acertain the mechanism of embryonic Bx by TP.

It is a new finding that apoptosis starts at the 18 th day of embryonic life, although some investigators have previously reported bursal apoptosis after hatching (МотукA and Reynolds, 1991 ; Paramithiotics et al., 1995). One possibilitiy of the detection of DNA fragmentation in normal chicks at day 18 of embryonic life was just under the conversion stage of somatic gene in B lymphocytes leading to Ig diversity (REYNAUD et al., 1994). This remodelling of bursa was perhaps accompanied by apoptosis. LYDYARD et al. (1976) and REYNAUD et al. (1994) have also reported that subpopulations of matured lymphocytes started their proliferations at day 18 of embyronic life. Therefore, apoptosis detected in the embryonic stage may coincide with the proliferation stage of lymphocytes and suggests an important stage for tissue remodelling in bursa.

It is well known that bursal cells begin to proliferate during the embryonic stage and the bursae show the highest weight at 8 weeks after hatching and remain at a constant level until 12 weeks (GLICK, 1956). However, there is a considerable variation in its proliferation and regresses (GLICK, 1956 ; LANDRETH and GLICK, 1973 ; YliKOMI et al., 1987). Some of them may be from strain difference in chickens (LANDRETH and GLICK, 1973). The bursa has involuted at about 3 to 6 months of age (Neiman, 1994 ; Reynaud et al., 1994). After the stage of maximal development, bursal cells can not proliferate furthermore and seem to migrate into peripheral lymphoid organs or become susceptibile to apoptotic induction. Bursal apoptosis has been shown by Мотүка and REYNOLDS (1991), who could easily detect apoptosis in young chickens aged 4, 7 and 10 weeks. The observations reported by MотүкA and REYNOLDS (1991) characterized an easy induction of bursal apoptosis at an early stage of natural involution. Therefore, this study is in line with eariler descriptions by MотукA and Reynolds (1991). However, it may be the first report on the mechanism of bursal involution after hatching in comparison with embryonic apoptosis.

It has been shown that genomic DNA undergoes a process of degradation prior to cell death in apoptosis (Compton et al., 1990). Many reports seemed to indicate apoptosis induction soon after stimulant treatment (HASBOLD and KLAUS, 1990 ; Wylli, 1980). TP administration into the allantoic cavity has a possible delaying effect on apoptosis induction. In this study, 'TUNEL, technique was not used to detect apoptotic cells but used tissue sections stained by toluidine blue or hematoxylin and eosin to differentiate cell types (ENGLish et al., 1989). Condensed chromatins by apoptosis were easily detected in the tissue sections stained with toluidine blue or hematoxylin and eosin. In such sections, only late stage of apoptosis can be detected and early ones could not be identified. Therefore, time course observation was introduced to examine the TP effects on bursa after hormonal injection.

There is a histological evidence that TP can suppress the proliferation of lymphoid follicles (Le Douarin et al., 1980 ; Olah et al., 1986). One possible mechanism of bursal involution is that the decreased function of epithelium resulting from TP treatment can not support the microenvironment for bursal development. In fact, previous 
report has demonstrated that bursal lymphocytes may be stimulate their proliferation by the factors released from the epithelium (Eerola, 1980 ; Eerola et al., 1982). Although apparent apoptosis was seen in bursal lymphocytes after hatching, present findings do not show any apparent induction of apoptosis in bursal lymphocy tes in the Bx embryos. This may be the difference between the natural involution of bursa by apoptosis after hatching and the bursa of TP-treated embryos. Missing the detection of morphological apoptosis in TP-treated bursa may arise from lower frequencies of apoptosis cells, especially in epithelial cells. Therefore, remaining problem to study is the undetectable apoptosis in the epithelial cells and immature lymphocytes.

It is an important problem to identify factor(s) for apoptosis induction in matured bursa. Bursal involution after the maturation stage and suppressive effects of TP on bursal development in chick embryos leads us to suggest that the level of male steroid hormone is an important factor for natural involution of bursa. However, LANDRETH and GLICK (1973) have described that organ involution started before sexual maturation. This controversial finding may be not surprising since the level of hormone receptors on the surface of target cells showed variations during the stage of sexual maturation. Furthermore, this suggests that unkonwn factor(s) may be responsible for physiological death of bursal cells. We are now investigating the factor responsible for bursal apoptosis.

\section{Acknowledgement}

The author would like to thank Prof. T. ODAKA for his critical reading of the manuscript.

\section{References}

CAREY, J. and N.L. WARNER (1964) Gamma-globulin synthesis in hormonally bursectomized chickens. Nature, 203 : 198-199.

Compton, M.M., P.S. GibBS and L.R. SwicEGood (1990) Glucocorticoid mediated activation of DNA degradation in avian lymphocytes. General and Comparative Endocrinology, $80: 68-79$.

EEROLA, E. (1980) In vitro culture of chicken bursal epithelium. Cellular Immunology, 53 : 162-172.

Eerola, E., O. Lassila, D.G. Gilmour and A. Tolvanen (1982) Induction of B cell differentiation in vitro by bursal epithelium. Journal of Immunology, $128: 2652-2655$.

ENGLISH, H.F., N. KYPRIANOU and J.T. IssaCS (1989) Relationship between DNA fragmentation and apoptosis in the programmed cell death in the rat prostate following castration. The Prostate $15: 233-250$.

GLICK, B. (1956) Normal growth of the bursa of Fabricius in chickens. Poultry Science, 35: 843-851.

HaSBolD, J. and G.G.B. Klaus (1990) Anti-immunoglobulin antibodies induce apoptosis in immature B cell lymphomas. European Journal of Immunology, 20 : 1685-1690.

LANDRETH, K.S. and B. GLICK (1973) Differential effect of bursectomy on antibody production in a large and small bursa line of New Hampshire chickens. Proceedings of the Society for Experimental Biology and Medicine, $144: 501-505$.

LE DouARin, N.M., G. Michel and E-E. BAulieu (1980) Studies of testosterone-induced involution of the bursa of Fabricius. Developmental Biology, $75: 288-302$.

Lydy ARD, P.M., C.E. Grossi and M.D. CoOper (1976) Ontogeny of B cells in the chicken. 1. Sequential development of clonal diversity in the bursa. Journal of Experimental Medicine, 144 : 79-95.

Meyaard, L., S.A. Otto, R.R. Jonker, M.J. Mijnster, R.P.M. Keet and F. Miedema (1992) Programmed death of T cells in HIV-1 infection. Science, $257: 217-219$. 
MORIYA, O. and Y. ICHIKAWA (1979) Accumulation of eosinophils and monocytes in lymphoid organs of chick embryos. II. Effect of mitogenic stimulation. Microbiology and Immunolology, $23: 523-531$.

МотукA, B. and J.D. Reynolds (1991) Apoptosis is associated with the extensive B cell death in the sheep ileal Peyer's patch and the chicken bursa of Fabricius : a possible role in B cell selection. European Journal of Immunology, 21 : 1951-1958.

NAGAHARA, M. (1991) DNA preparations for experimental material, In 'Southern, Northern, Western Blotting (Kuchino Y, H. Hirai and I. Sakurabayasi, eds.)', pp. 21-25. Soft Science, Tokyo, (in Japanese).

Neiman, P.E. (1994) Retrovirus-induced B cell neoplasia in the bursa of Fabricius. Advances in Immunology, $56:$ 467-484.

OlAH, I., B. Glick and I. TORO (1986) Bursal development in normal and testosterone treated chick embryos. Poultry Science, 65 : 574-588.

Paramithiotics. E., K.A. Jacoksen and M.J.H. Ratcliffe (1995) Loss of surface immunoglobulin expression precedes B cell death by apoptosis in the bursa of Fabricius. Journal of Experimental Medicine, $181: 105-113$.

Reynaud, C-A., B. Ertocci, A. Dahan and J-C. Weill (1994) Formation of the chicken B-cell repertorie : Ontogenesis, regulation of Ig gene rearrangement, and diversification by gene convertion. Advances in Immunology, $57: 353-377$.

Schwartz, L.M., W. Smith, M.E. Jones and B.A. Osborne (1993) Do all programmed cell deaths occur via apoptosis? Proceedings of the National Academy of Sciences (USA), 90 : 980-984.

Soos, G., I. Olah, Z. KitTner, I. TORo and B. Glick (1990) Effect of the progestogen, allylestriol, on the bursal development of the chicken. Developmental and Comparative Immunology, 14 : 457-463.

SzenBerG, A. and N.L. W ARner (1962) Dissociation of immunological responsiveness in fowls with hormonally arrested development of lymphoid tissues. Nature, $194: 146-147$.

WyLLI, A.H. (1980) Glucocorticoid induced thymocyte apoptosis is associated with endogeneous endonuclease activation. Nature, $284: 555-556$.

Ylikomi, T.J., J.J. Isola, J-M. GASC and P.J. TuohimaA (1987) Sexual maturation associated and estrogen-induced progesterone receptor expression in the bursa of Fabricius. Journal of Immunology, $138: 3174-3178$. 


\section{ニワトリにおけるアポトーシスとファブリシウス襄の消失 \\ 守屋 修 \\ 埼玉医科大学, 入間郡毛呂山町 350-04}

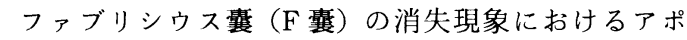
トーシスの関与について検討した。アポトーシスは正常 に発育している 18 日齢胚の $\mathrm{F}$ 囊で初めて検出され, F 衰でのアポトーシスは特定の発生過程で発現すると考え られた。F 霊消失を誘発するテストステロンプロピオ ネート (TP) を処置 (化学的 $\mathrm{F}$ 囊除去) した胚の $\mathrm{F}$ 異で は, 18 日齢でのみ DNA 断片化を指標にしたアポトーシ スが観察された。しかし形態観察では F 輬のリンパ球や 上皮細胞に広範なアポトーシス像は認められなかった。 化学的に F 慗の消失を起こす半量の TP を処置をした 胚では, 低レベルの DNA 断片化の反応が.18 日齢以降,
常に認められたが，アポトーシスを示す細胞数の割合は 低かった。一方, 粰化後の正常 $\mathrm{F}$ 糞ではアポトーシスの 現象が容易に観察された。特に性的成熟後の $\mathrm{F}$ 襄でアポ トーシスが顕著であり，成熟後にみられる生理的で自然 な F 襄の消失過程におけるアポトーシスの関与が強く 示峻された。しかし，化学的除去による F 䡬消失はアポ トーシスに非依存的で, 成熟後に見られる $\mathrm{F}$ 襄消失とは 異なる機構によると思われた。

（家离会誌，35：37-46，1998） キーワード : ブァブリシウス襄, 化学的 $\mathrm{F}$ 軩除去, アポ トーシス, ニワトリ 